\title{
ANP32C wt Allele
}

National Cancer Institute

\section{Source}

National Cancer Institute. ANP32C wt Allele. NCI Thesaurus. Code C54326.

Human ANP32C wild-type allele is located in the vicinity of $4 q 32.3$ and is approximately 1 kbin length. This allele, which encodes acidic leucine-rich nuclear phosphoprotein 32 family member $\mathrm{C}$ protein, is involved in tumorigenesis for several types of cancer. 